\author{
Masahiro Irifune DDS PhD, ${ }^{\star \dagger}$ \\ Tomoaki Sato DDS PhD, * \\ Yoshiko Kamata, * \\ Takashige Nishikawa PhD, * \\ Masahiro Nomoto MD PhD, \\ Takeo Fukuda MD PhD, ${ }^{\ddagger}$ \\ Michio Kawahara MD PhD ${ }^{\dagger}$
}

\section{Inhibition by diazepam of ketamine-induced hyperlocomotion and dopamine turnover in mice}

Purpose: To investigate the effects of the benzodiazepine diazepam on ketamine-induced hyperlocomotion and dopamine turnover.

Methods: Adult male ddY mice were used $(n=218)$. Locomotor activity was measured with four circular activity cages equipped with three photocell sensor units. Interruptions by a mover of the infrared light beams were recorded on electromechanical counters, and automatically printed every 10 min for three hours after the ketamine injection. All drugs were administered intraperitoneally $(i p)$. The concentrations of dopamine and its metabolites in discrete brain regions were measured by high performance liquid chromatography with electrochemical detection.

Results: Ketamine ( $30 \mathrm{mg} \mathrm{kg}^{-1}$ ) increased total locomotor activity counts for three hours to $442 \%$ of control in mice $(P=0.000 \mathrm{I})$. Diazepam, 3 and $10 \mathrm{mg} \mathrm{kg}^{-1}$, inhibited, in a dose-dependent fashion, this ketamine-induced hyperlocomotion by $26 \%(P=0.011 \mathrm{I})$ and $59 \%(P=0.0001)$, respectively. Regional brain dopamine assays revealed that ketamine $\left(30 \mathrm{mg}^{-1} \mathrm{~kg}^{-}\right)$increased the homovanillic acid:dopamine ratio (one indicator of dopamine turnover) to $121 \%$ of control in the nucleus accumbens $(P=0.0065)$ and to $111 \%$ in the striatum $(P=0.0135)$ at peak locomotion. Diazepam, 3 and $10 \mathrm{mg}^{\mathrm{kg}}{ }^{-1}$, returned this increase in dopamine turnover produced by ketamine to control levels both in the nucleus accumbens $(P=0.0061$ and $P=0.0117$, respectively) and in the striatum $(P=0.0004$ and $P=$ 0.0047 , respectively).

Conclusion: These results suggest that the inhibition by diazepam of ketamine-induced hyperlocomotion may be related to its ability to suppress the activation of dopamine neurons in the nucleus accumbens and striatum.

Objectif : Examiner les effets d'une benzodiazepine, le diazépam, sur l'hyperactivité locomotrice et le turnover de la dopamine induits par la kétamine.

Méthodes : Deux cent dix-huit souris adultes mâles de souche ddY ont été utilisées. L'activité locomotrice a été mesurée au moyen de quatre cages d'activité circulaire équipée de trois cellules de détection photo-électriques. Les internuptions par un animal en mouvement des faisceaux infrarouges étaient enregistrées par des totalisateurs électromécaniques et automatiquement imprimées à toutes les 10 minutes durant trois heures après l'injection de kétamine. Tous les médicaments ont été administrés par voie intrapéritonéale (ip). Les concentrations de dopamine et de ses métabolites dans des régions précises du cerveau ont été mesurées par chromatographie liquide à haute performance avec détection électrochimique.

Résultats : Durant les trois heures après son administration, la kétamine $\left(30 \mathrm{mg}^{\mathrm{kg}}{ }^{-1}\right)$ a augmenté le décompte total de l'activité locomotrice de $442 \%$ par rapport au contrôle $(P=0,0001)$. Le diazépam a inhibé de façon proportionnelle à la dose cette hyperactivité locomotrice induite par la kétamine à raison de $26 \%$ pour la dose de $3 \mathrm{mg} \cdot \mathrm{kg}^{-1}$ $\left(P=0,0\right.$ I I I ) et de $59 \%(P=0,000 \mathrm{I})$ pour la dose de $10 \mathrm{mg} \mathrm{kg}^{-1}$. Les mesures de dopamine cérébrale ont démontré que la kétamine à la dose utilisée augmentait le rapport acide homovanilique : dopamine (ce rapport est un indicateur du turnover de la dopamine) à $121 \%$ du contrôle dans le noyau accumbens $(P=0,0065)$ et à $111 \%$ dans le corps strié $(P=0,0135)$, ces mesures étant faites au pic de l'activité locomotrice. Le diazépam, aux doses de 3 et $10 \mathrm{mg} \cdot \mathrm{kg}^{-1}$, a ramené à la normale l'accroissement du turnover de la dopamine produit par la kétamine, à la fois dans le noyau accumbens $(P=0,0061$ et $P=0,0117$ respectivement) et dans le corps strié $(P=0,0004$ et $P=0,0047)$.

Conclusion : Ces résultats suggèrent que l'inhibition par le diazépam de l'hyperactivité locomotrice induite par la kétamine peut être en relation avec sa capacité de suppression de l'activation des neurones dopaminergiques dans le noyau accumbens et dans le corps strié.

From the Department of Pharmacology, Kagoshima University Dental School, Kagoshima, Japan, * Department of Pharmacology, Kagoshima University Medical School, Kagoshima, Japan, ${ }^{\ddagger}$ and Department of Anesthesiology, Hiroshima University Dental Hospital, 1-2-3 Kasumi, Minami-ku, Hiroshima 734-8553, Japan. ${ }^{\top}$ This work was performed at the Departments of Pharmacology, Kagoshima University Dental School and Kagoshima University Medical School, Kagoshima, Japan. This work was supported in part by a Grant-in-Aid for Scientific Research (No. 06671863) from the Ministry of Education, Science, Sports and Culture, Japan.

Address correspondence to: Masahiro Irifune DDS PhD, Department of Anesthesiology, Hiroshima University Dental Hospital, 1-2-3 Kasumi, Minami-ku, Hiroshima 734-8553, Japan. Phone: 81-82-257-5786; Fax: 81-82-257-5779.

Accepted for publication February 7, 1998. 
$\mathrm{K}$

ETAMINE is an intravenous anaesthetic characterized by rapid onset of action, analgesia, lack of cardiorespiratory depression, and a wide margin of safety. Emergence from ketamine anaesthesia, however, is often accompanied by restlessness, mood changes, psychomotor agitation, and hallucinations in humans. ${ }^{1}$ The high incidence of such emergence reactions has limited its widespread clinical acceptance. ${ }^{2}$ A number of drugs have been used to reduce the incidence and severity of postoperative reactions to ketamine; the benzodiazepines, diazepam, midazolam and lorazepam, are thought to be the most effective group of drugs to attenuate or treat ketamine emergence reactions. It is probable that both the sedative and amnesic actions of the benzodiazepines make them superior to other sedative hypnotics. The precise mechanism of this action is not known. ${ }^{3}$

In behavioural studies, ketamine has been reported to produce a variety of stimulant actions including hyperlocomotion in rodents. ${ }^{4-6}$ Drugs such as amphetamine, ${ }^{7}$ cocaine ${ }^{8}$ and L-3,4-dihydroxyphenylalanine (L-DOPA), ${ }^{9}$ which produce hyperlocomotion in rodents, are known to induce agitation, hallucinations and psychosis in humans. Both the hyperlocomotion in rodents and the symptoms in humans induced by these drugs are believed to be mediated by activation of dopamine neurons. Neurochemically, it has been demonstrated that ketamine increases dopamine turnover in the nucleus accumbens $s^{6,10}$ and the striatum ${ }^{6,10,11}$ in rodents, and that ketamineinduced hyperlocomotion is associated with this increased dopamine turnover. ${ }^{6,11}$ These findings suggest that the psychotomimetic reactions of ketamine, such as mood changes, psychomotor agitation and hallucinations, are due to the activation of dopamine neurons. $\gamma$-Aminobutyric acid (GABA) pathways in the central nervous system can alter locomotor activity if sufficiently stimulated or inhibited, since GABA interacts directly with dopamine neurons in an inhibitory capacity. ${ }^{12}$ The benzodiazepines are known to enhance GABA neurotransmission, ${ }^{13}$ and, consequently, decrease dopamine turnover in the nucleus accumbens and the striatum in rodents. ${ }^{14,15}$ Therefore, in this study, the effects of the benzodiazepine diazepam on ketamine-induced hyperlocomotion and dopamine turnover were examined in mice.

\section{Methods}

These studies were carried out according to protocols approved by the Committee on Animal Experimentation, Kagoshima University Dental School.

\section{Animals}

Adult male ddY mice (Kuroda Junkei Doubutsu Ltd., Kumamoto, Japan) weighing $35-49 \mathrm{~g}$ were used. Each animal was used once, and one trial per animal was conducted in either a behavioural or neurochemical study. The animals were housed with free access to food and water in an air-conditioned room maintained at $22-24^{\circ} \mathrm{C}$ and with a humidity level of $45-55 \%$ under a constant 12-hr light-dark cycle (lights on at 7:00 AM). All behavioural experiments were performed between 10:00 $\mathrm{AM}$ and 6:00 PM.

\section{Locomotor activity}

Locomotor activity was measured with four circular activity cages that measured $49 \mathrm{~cm}$ diameter $\times 26.5 \mathrm{~cm}$ high. Each cage was equipped with three photocell sensor units mounted on the outer wall at equal distances $2 \mathrm{~cm}$ above the floor. Interruptions by a mover of the infrared light beams were recorded on electromechanical counters (WPC 101-4, Watanabe Denshi Seisakusho Co., Fukuoka, Japan) located at a distance from the activity cages and automatically printed every $10 \mathrm{~min}$. Mice were placed in individual cages and allowed to become acclimated to the cage for $30 \mathrm{~min}$. Ketamine (30 $\mathrm{mg} \cdot \mathrm{kg}^{-1}$ ) or saline was then administered ip. Thereafter, the mice were immediately returned to the cages for an additional three-hour test period. Diazepam (1-10 mg. $\mathrm{kg}^{-1}$ ) or the vehicle was administered $30 \mathrm{~min}$ before the ketamine injection.

\section{Assay procedure}

Dopamine, 3,4-dihydroxyphenylacetic acid (DOPAC) and homovanillic acid (HVA) were measured as follows. The mice were decapitated $20 \mathrm{~min}$ after the $i p$ administration of ketamine $\left(30 \mathrm{mg} \cdot \mathrm{kg}^{-1}\right)$ with or without pretreatment of diazepam (1-10 $\left.\mathrm{mg} \cdot \mathrm{kg}^{-1}\right)$, when the effects of ketamine at this dose on locomotor activity were approximately at a peak. Control animals were treated with saline or vehicle solution, and killed on a similar schedule.

The brain was quickly removed and dissected on an ice-cold glass plate into the frontal cortex, nucleus accumbens (including olfactory tubercle) and striatum according to the method of Heffner et al., ${ }^{16}$ slightly modified. Briefly, these regions were dissected with a razor blade from the coronal brain slice that included all three regions. The brain parts were weighed, frozen on dry ice, and stored at $-40^{\circ} \mathrm{C}$ until assayed. The tissue sample was homogenized in $0.1 \mathrm{M}$ perchloric acid containing $5 \mathrm{mM}$ ethylenediaminetetraacetic acid (EDTA) and $25 \mathrm{pg} \cdot \mathrm{\mu l}^{-1}$ of 3,4-dihydroxybenzylamine, using an ultrasonic cell disruptor (40\% pulsed power for $30 \mathrm{sec}$; 
Model 185, Branson, Danbury, CT), and centrifuged at $28,000 \mathrm{~g}$ for $20 \mathrm{~min}$ at $4^{\circ} \mathrm{C}$ (KR-20000T, Kubota Seisakusho Co., Tokyo, Japan). The supernatant was filtered through a $0.45-\mu \mathrm{m}$ membrane filter (LC3A, Gelman Sciences, Ann Arbor, MI) and a 20- $\mu$ aliquot of the filtered solution was injected into a high performance liquid chromatography (HPLC) with electrochemical detection. The HPLC system consisted of a delivery pump (Waters 510, Waters Associates, Milford, MA), a sample injector (WISP 710B, Waters Associates), a reverse phase column $(250 \mathrm{~mm}$ length $\times 4.6 \mathrm{~mm}$ internal diameter; Eicompak MA-ODS, Eikom Co., Kyoto, Japan), an electrochemical detector (LC-4B, Bioanalytical Systems Inc., West Lafayette, IN) set at a potential of $+0.8 \mathrm{~V} v s$ an $\mathrm{Ag} / \mathrm{AgCl}$ reference electrode and a computing integrator-printer (Waters 740, Waters Associates). The analytical column temperature was controlled at $40^{\circ} \mathrm{C}$. The mobile phase consisted of $12 \%(\mathrm{v} / \mathrm{v})$ methanol containing $0.1 \mathrm{M}$ sodium acetate, $0.1 \mathrm{M}$ citric acid, $0.23 \mathrm{mM}$ sodium octyl sulfate and $1.6 \mathrm{mM}$ EDTA adjusted to $\mathrm{pH} 3.90$, and was pumped through the column at a rate of $1 \mathrm{ml} \cdot \mathrm{min}^{-1}$.

\section{Drugs and solutions}

Ketamine hydrochloride was purchased from Research Biochemicals Inc. (Wayland, MA), and diazepam was from Wako Pure Chemical Industries Ltd. (Osaka, Japan). Ketamine was dissolved in saline $0.9 \%$ solution. Diazepam was suspended in carboxymethyl cellulose salt $1.0 \%$ solution. Each drug was freshly prepared on the day of the experiment.

All drugs were administered in a volume of $5 \mathrm{ml} \cdot \mathrm{kg}^{-1} i p$. Concurrent control groups were used in each experiment. Treatments for subjects in a given group were always applied over two or more days. Two or more different treatments were carried out on the same day.

\section{Statistical analysis}

The data were analysed by one-way analysis of variance (ANOVA) followed by Fisher's least significant difference (LSD) test for multiple comparisons or by twoway factorial ANOVA. The results were considered significant at $P<0.05$. The results in the text, figure and tables are expressed as the means $\pm S E M$.

\section{Results}

\section{Effect of ketamine on locomotor activity}

An injection of $30 \mathrm{mg} \cdot \mathrm{kg}^{-1}$ of ketamine ip in mice increased total locomotor activity counts for three hours compared with vehicle control $[1365.6 \pm 128.4$ $(\mathrm{n}=8)$ ps $308.7 \pm 56.1(\mathrm{n}=8)(P=0.0001)]$. The

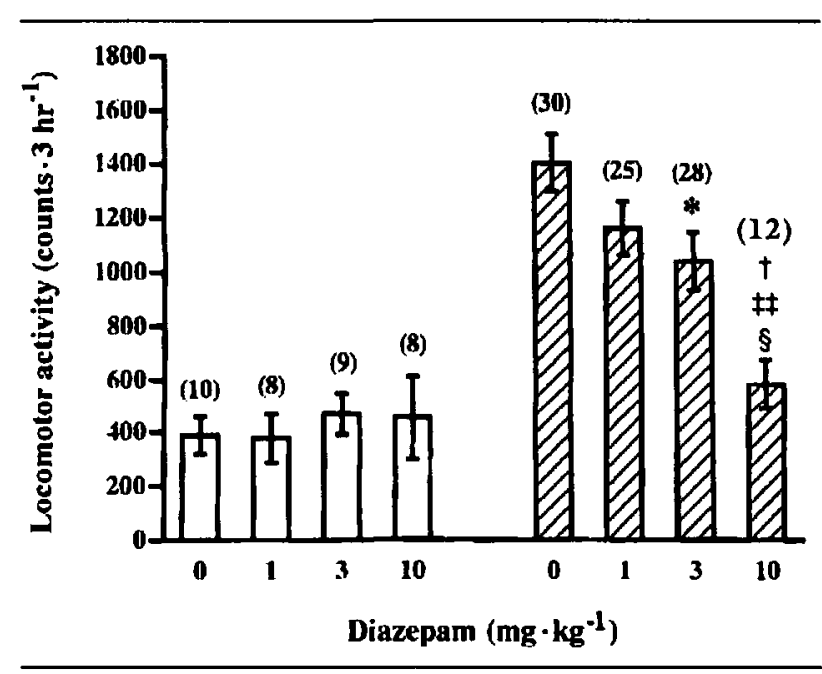

FIGURE Effect of diazepam on hyperlocomotion induced by $30 \mathrm{mg} \cdot \mathrm{kg}^{-1} \mathrm{ketamine}$ ip in mice. Various doses of diazepam or the vehicle were administered ip 30 min before ketamine (hatched bars) or saline (open bars). The cumulative locomotor activity counts were determined as the total of each 10 -min count for $3 \mathrm{hr} .{ }^{*} P<0.05$, $\uparrow P<0.01$ compared with ketamine alone group, $¥ ¥ P<0.01$ compared with $1 \mathrm{mg} \cdot \mathrm{kg}^{-1}$ diazepam + ketamine group, $\$ P<0.05$ compared with $3 \mathrm{mg} \cdot \mathrm{kg}^{-1}$ diazepam + ketamine group. Each bar represents the mean \pm SEM. Numbers in parentheses indicate the number of animals used in each experiment.

peak locomotion of this dose of ketamine occurred within the first $20 \mathrm{~min}$. Thereafter, the activity rapidly declined and returned to the control level at approximately $60 \mathrm{~min}$ after the injection.

Effect of diazepam on ketamine-induced hyperlocomotion Various doses of diazepam (1-10 $\mathrm{mg} \cdot \mathrm{kg}^{-1}$ ) dose dependently inhibited the hyperlocomotion induced by $30 \mathrm{mg} \cdot \mathrm{kg}^{-1}$ of ketamine. Diazepam, 3 and 10 $\mathrm{mg} \cdot \mathrm{kg}^{-1}$, suppressed this ketamine-induced hyperlocomotion by $26 \%(P=0.0111)$ and $59 \%(P=0.0001)$, respectively. These doses of diazepam did not, on their own, interfere with the animals' spontaneous locomotor activity $(P=0.8855)$ (Figure). Two-way factorial ANOVA revealed a significant diazepam dose $(0,1,3$ and $\left.10 \mathrm{mg} \cdot \mathrm{kg}^{-1}\right)$ and ketamine (treated or untreated) interaction $(P=0.0176)$.

\section{Effect of diazepam on ketamine-induced increase in dopamine turnover}

As shown in Table I, $30 \mathrm{mg} \cdot \mathrm{kg}^{-1}$ ketamine increased the DOPAC:dopamine ratio (one indicator of dopamine turnover) to $126 \%$ of control in the nucleus accumbens $(P=0.0016)$ at peak locomotion. Diazepam, 3 and 10 $\mathrm{mg} \cdot \mathrm{kg}^{-1}$, reduced this ketamine-induced increase in dopamine turnover to $110 \%(P=0.0459)$ and $108 \%$ $(P=0.0249)$ of control, respectively. Similarly, 30 
TABLE I Effect of diazepam (DZP) on the increase in dopamine (DA) turnover induced by $30 \mathrm{mg} \cdot \mathrm{kg}^{-1}$ of ketamine (Ket) ip in mice

\begin{tabular}{|c|c|c|c|c|c|}
\hline $\begin{array}{l}\text { Region and } \\
\text { treatment (mg.kg-1) }\end{array}$ & $\begin{array}{c}D A \\
\left(n g \cdot \mathscr{g}^{-1} \text { tissue) }\right.\end{array}$ & $\begin{array}{c}D O P A C \\
\left(n g \cdot \mathscr{G}^{-1} \text { tissue) }\right.\end{array}$ & $\begin{array}{c}H V A \\
\left(n g \cdot g^{-1} \text { tissue) }\right.\end{array}$ & $\begin{array}{l}\text { DOPAC: } \\
D A \text { ratio }\end{array}$ & $\begin{array}{l}\text { HVA: } \\
D A \text { ratio }\end{array}$ \\
\hline \multicolumn{6}{|l|}{ Frontal cortex } \\
\hline Control & $31 \pm 2$ & $47 \pm 2$ & $147 \pm 7$ & $1.548 \pm 0.075$ & $4.806 \pm 0.212$ \\
\hline Ket & $34 \pm 2$ & $51 \pm 2$ & $155 \pm 3$ & $1.512 \pm 0.063$ & $4.655 \pm 0.278$ \\
\hline $\mathrm{DZP}(1)+\mathrm{Ket}$ & $37 \pm 3$ & $53 \pm 5$ & $164 \pm 6$ & $1.428 \pm 0.045$ & $4.567 \pm 0.233$ \\
\hline$D Z P(3)+$ Ket & $39 \pm 2$ & $55 \pm 3$ & $166 \pm 6$ & $1.447 \pm 0.119$ & $4.380 \pm 0.313$ \\
\hline $\mathrm{DZP}(10)+\mathrm{Ket}$ & $38 \pm 3$ & $48 \pm 3$ & $182 \pm 12^{\dagger \S}$ & $1.309 \pm 0.077$ & $4.953 \pm 0.353$ \\
\hline \multicolumn{6}{|l|}{ Nucleus accumbens } \\
\hline Control & $6545 \pm 301$ & $1165 \pm 47$ & $977 \pm 42$ & $0.180 \pm 0.009$ & $0.151 \pm 0.007$ \\
\hline Ket & $6820 \pm 430$ & $1527 \pm 90^{\dagger}$ & $1226 \pm 64^{t}$ & $0.226 \pm 0.008^{\dagger}$ & $0.182 \pm 0.007^{t}$ \\
\hline DZP $(1)+$ Ket & $6847 \pm 349$ & $1477 \pm 118^{\dagger}$ & $1192 \pm 88^{*}$ & $0.216 \pm 0.013^{*}$ & $0.173 \pm 0.008^{*}$ \\
\hline $\mathrm{DZP}(3)+\mathrm{Ket}$ & $7356 \pm 276$ & $1448 \pm 66^{*}$ & $1095 \pm 46$ & $0.198 \pm 0.010^{\ddagger}$ & $0.150 \pm 0.00991$ \\
\hline $\mathrm{DZP}(10)+\mathrm{Ket}$ & $7423 \pm 290$ & $1439 \pm 61^{*}$ & $1129 \pm 44$ & $0.194 \pm 0.007 \ddagger$ & $0.153 \pm 0.007^{t}$ \\
\hline \multicolumn{6}{|l|}{ Striatum } \\
\hline Control & $13439 \pm 483$ & $1485 \pm 83$ & $1894 \pm 83$ & $0.111 \pm 0.005$ & $0.141 \pm 0.004$ \\
\hline Ket & $13378 \pm 225$ & $1634 \pm 65$ & $2091 \pm 41$ & $0.122 \pm 0.003$ & $0.156 \pm 0.002 *$ \\
\hline $\mathrm{DZP}(1)+\mathrm{Ket}$ & $14198 \pm 263$ & $1622 \pm 73$ & $1974 \pm 55$ & $0.115 \pm 0.006$ & $0.139 \pm 0.002^{\S}$ \\
\hline $\mathrm{DZP}(3)+\mathrm{Ket}$ & $13360 \pm 393$ & $1506 \pm 76$ & $1779 \pm 68^{\$}$ & $0.113 \pm 0.006$ & $0.134 \pm 0.005^{5}$ \\
\hline DZP $(10)+$ Ket & $13902 \pm 541$ & $1492 \pm 64$ & $1919 \pm 89$ & $0.108 \pm 0.004^{\ddagger}$ & $0.139 \pm 0.006^{\$}$ \\
\hline
\end{tabular}

Data are the means $\pm S E M$ of eight animals.

${ }^{*} P<0.05, t P<0.01$ compared with control group, $\$ P<0.05, \$ P<0.01$ compared with ketamine alone group,

$\mathbb{I} P<0.05$ compared with $1 \mathrm{mg} \cdot \mathrm{kg}^{-1}$ diazepam + ketamine group.

TABLE II Effect of diazepam (DZP) on dopamine (DA) turnover in mice

\begin{tabular}{|c|c|c|c|c|c|}
\hline $\begin{array}{l}\text { Region and } \\
\text { treatment (mg.kg-i) }\end{array}$ & $\begin{array}{c}D A \\
\left(n g \cdot g^{-1} \text { tissue }\right)\end{array}$ & $\begin{array}{c}D O P A C \\
\left(n g \cdot \mathscr{G}^{-1} \text { tissue }\right)\end{array}$ & $\begin{array}{c}H V A \\
\left(n g \cdot \mathscr{G}^{-1} \text { tioue }\right)\end{array}$ & $\begin{array}{l}\text { DOPAC: } \\
D A \text { ratio }\end{array}$ & $\begin{array}{l}\text { HVA: } \\
D A \text { ratio }\end{array}$ \\
\hline $\begin{array}{l}\text { Frontal cortex } \\
\text { Control } \\
\text { DZP (1) } \\
\text { DZP (3) } \\
\text { DZP (10) }\end{array}$ & $\begin{array}{l}28 \pm 2 \\
37 \pm 6 \\
36 \pm 3 \\
45 \pm 7\end{array}$ & $\begin{array}{l}48 \pm 3 \\
50 \pm 3 \\
49 \pm 2 \\
50 \pm 3\end{array}$ & $\begin{array}{l}141 \pm 9 \\
130 \pm 7 \\
136 \pm 8 \\
124 \pm 8\end{array}$ & $\begin{array}{l}1.717 \pm 0.056 \\
1.481 \pm 0.115 \\
1.448 \pm 0.123 \\
1.221 \pm 0.124^{\dagger}\end{array}$ & $\begin{array}{l}5.112 \pm 0.322 \\
3.968 \pm 0.472 \\
4.065 \pm 0.439 \\
3.123 \pm 0.341^{\dagger}\end{array}$ \\
\hline $\begin{array}{l}\text { Nucleus accumbens } \\
\text { Control } \\
\text { DZP (1) } \\
\text { DZP (3) } \\
\text { DZP (10) }\end{array}$ & $\begin{array}{l}5981 \pm 264 \\
6395 \pm 512 \\
7110 \pm 574 \\
7157 \pm 385\end{array}$ & $\begin{array}{l}1582 \pm 1125 \\
1660 \pm 81 \\
1620 \pm 163 \\
1710 \pm 173\end{array}$ & $\begin{array}{r}1019 \pm 62 \\
946 \pm 20 \\
975 \pm 42 \\
929 \pm 49\end{array}$ & $\begin{array}{l}0.269 \pm 0.025 \\
0.276 \pm 0.031 \\
0.244 \pm 0.038 \\
0.247 \pm 0.032\end{array}$ & $\begin{array}{l}0.170 \pm 0.007 \\
0.155 \pm 0.013 \\
0.141 \pm 0.009 \\
0.133 \pm 0.011\end{array}$ \\
\hline $\begin{array}{l}\text { Striatum } \\
\text { Control } \\
\text { DZP (1) } \\
\text { DZP (3) } \\
\text { DZP (10) }\end{array}$ & $\begin{array}{l}13455 \pm 661 \\
14335 \pm 382 \\
14086 \pm 427 \\
14395 \pm 463\end{array}$ & $\begin{array}{l}1661 \pm 53 \\
1654 \pm 62 \\
1570 \pm 86 \\
1600 \pm 94\end{array}$ & $\begin{array}{l}1911 \pm 113 \\
1753 \pm 64 \\
1662 \pm 71^{\star} \\
1563 \pm 66^{\dagger}\end{array}$ & $\begin{array}{l}0.125 \pm 0.004 \\
0.116 \pm 0.004 \\
0.111 \pm 0.004 \\
0.111 \pm 0.006\end{array}$ & $\begin{array}{l}0.143 \pm 0.006 \\
0.123 \pm 0.005^{\dagger} \\
0.118 \pm 0.003^{\dagger} \\
0.109 \pm 0.006^{\dagger}\end{array}$ \\
\hline
\end{tabular}

Data are the means \pm SEM of eight animals.

* $P<0.05,{ }^{\dagger} P<0.01$ compared with control group.

$\mathrm{mg} \cdot \mathrm{kg}^{-1} \mathrm{ketamine}$ increased the HVA:dopamine ratio to $121 \%$ of control in the nucleus accumbens $(P=0.0065)$ and to $111 \%$ in the striatum $(P=0.0135)$ at peak locomotion, but not in the frontal cortex $(P=0.6611)$. Diazepam, even at $3 \mathrm{mg} \cdot \mathrm{kg}^{-1}$, returned the increase in dopamine turnover produced by ketamine to the control level both in the nucleus accumbens $(P=0.0061)$ and in the striatum $(P=0.0004)$.
In the frontal cortex, diazepam alone at high dose (10 $\mathrm{mg} \cdot \mathrm{kg}^{-1}$ ) decreased the HVA:dopamine ratio to $61 \%$ of control $(P=0.0015)$. Diazepam alone at 3 and $10 \mathrm{mg} \cdot \mathrm{kg}^{-1}$ reduced the ratio to $83 \%(P=0.0499)$ and $78 \%(P=0.0136)$ of control, respectively, in the nucleus accumbens, and to $83 \%(P=0.0018)$ and $76 \%(P=0.0001)$, respectively, in the striatum (Table II). 


\section{Discussion}

The present study showed that ketamine $\left(30 \mathrm{mg} \cdot \mathrm{kg}^{-1}\right)$ increased locomotor activity, and consistently increased dopamine turnover in the nucleus accumbens and striatum at peak locomotion (Table I), suggesting that ketamine-induced hyperlocomotion is associated with the increased dopamine turnover in these regions. The benzodiazepine diazepam ( 3 and $10 \mathrm{mg} \cdot \mathrm{kg}^{-1}$ ) inhibited both the hyperlocomotion and the increase in dopamine turnover in the nucleus accumbens and striatum produced by ketamine $\left(30 \mathrm{mg} \cdot \mathrm{kg}^{-1}\right)$ (Figure, Table I). These results suggest that the inhibition by diazepam of ketamine-induced hyperlocomotion may be related to its ability to inhibit the increased dopamine turnover in the nucleus accumbens and striatum.

In turnover studies on neurotransmitters in the central nervous system, it is usually assumed that the transmitter is in a steady state (rate of synthesis equals rate of removal or metabolism), or that the synthesis or breakdown has been completely blocked by an enzyme inhibitor, in which case the rate of depletion or accumulation of transmitter can be determined as an estimate of turnover. ${ }^{17}$

In dopamine synthesis, conversion of L-tyrosine to L-DOPA by the enzyme tyrosine hydroxylase is the rate- limiting step. DOPA is subsequently converted to dopamine by L-aromatic amino acid decarboxylase. Invasion of dopaminergic nerve terminals by impulse flow results in calcium-dependent release of dopamine. Released dopamine is metabolized to DOPAC by intraneuronal monoamine oxidase (MAO) after reuptake by the nerve terminal. Released dopamine is also converted to HVA, probably at an extraneuronal site through the sequential action of catechol-0-methyltransferase (COMT) and MAO. ${ }^{18}$ The decline in the concentration of dopamine following the inhibition of its synthesis by $\alpha$-methyltyrosine, an inhibitor of tyrosine hydroxylase, is often used as an index of dopamine turnover, assuming steady state kinetics to prevail during the period of enzyme inhibition. ${ }^{19}$ It has been reported that the data for the changes in dopamine levels after synthesis inhibition with $\alpha$-methyltyrosine are consistent with those for dopamine metabolite:dopamine ratios. Thus, dopamine metabolite:dopamine ratios can be indicators of faster transmitter turnover. ${ }^{20,21}$ Furthermore, the onset of action of $\alpha$-methyltyrosine is known to be slow. ${ }^{19}$ In this study, $\alpha$-methyltyrosine was not used because the onset of the action of ketamine $\left(30 \mathrm{mg} \cdot \mathrm{kg}^{-1}, i p\right)$ on dopamine turnover is much faster than that of the enzyme inhibitor.

The primary metabolites of dopamine in the central nervous system are DOPAC and HVA, and the shortterm accumulation of these metabolites may provide an accurate reflection of activity in dopaminergic neurons. Drugs that increase impulse flow also increase levels of DOPAC and HVA, and dopamine turnover. Drugs that block or decrease impulse flow reduce these metabolites and the turnover. Thus, there appears to be an excellent correlation between changes in impulse flow in dopaminergic neurons and changes in DOPAC and HVA, and in dopamine turnover. As might be predicted, however, drugs that act in the central nervous system can have various effects, which can alter the turnover without necessarily altering impulse flow in the dopaminergic system being studied. Therefore, the most direct way to determine if a drug alters impulse flow in the dopaminergic system is to measure the activity of that system (e.g., a behavioural change) while the animal is under the influence of the drug. ${ }^{18}$

We previously reported in a behavioural study that ketamine (3-150 $\mathrm{mg} \cdot \mathrm{kg}^{-1}$ ) dose dependently produces hyperlocomotion in mice. A high dose of ketamine (150 mg. $\mathrm{kg}^{-1}$ ) induces hyperlocomotion approximately twice as much as does a low dose $\left(30 \mathrm{mg} \cdot \mathrm{kg}^{-1}\right)$. However, the higher dose of ketamine also induces anaesthesia, and hyperlocomotion occurs after the anaesthetic phase. Therefore, the properties of hyperlocomotion produced by anaesthetic doses may be different from those produced by lower doses. In fact, the neurochemical properties of the anaesthetic dose of ketamine (150 mg. $\mathrm{kg}^{-1}$ ) are different from those of the lower dose $\left(30 \mathrm{mg} \cdot \mathrm{kg}^{-1}\right)$ : the lower dose selectively increases dopamine turnover in the nucleus accumbens and striatum at peak locomotion, while the higher dose increases not only dopamine but also norepinephrine and serotonin (5-hydroxytryptamine, 5-HT) turnover in many regions of the brain. ${ }^{6}$ For these reasons, in the present study, we used a dose of $30 \mathrm{mg} \cdot \mathrm{kg}^{-1}$ for ketamine and focused on dopamine neurons.

It has been demonstrated that ketamine-induced hyperlocomotion is enhanced by co-administration of the indirect dopamine receptor agonists methamphetamine and cocaine, and the dopamine uptake inhibitor GBR 12909. In addition, ketamine-induced locomotor hyperactivity is suppressed by the dopamine receptor antagonist haloperidol, the destruction of dopaminergic terminals by 6-hydroxydopamine, and the inhibition of dopamine synthesis by $\alpha$-methyl-p-tyrosine. ${ }^{6,22}$ It appears, therefore, that ketamine-induced hyperlocomotion is mediated by the stimulation of dopamine neurons. Drugs that stimulate dopamine neurons are known to produce hyperlocomotion in rodents, and to induce agitation, hallucinations and psychosis in humans. Thus, these findings support the clinical evidence that the dopamine receptor antagonist droperidol decreases the incidence of restlessness, crying, screaming, hallucina- 
tions and vomiting associated with recovery from ketamine anaesthesia, ${ }^{23,24}$ although droperidol may increase the occurrence of vivid dreams. ${ }^{2}$

Major central dopaminergic pathways include the long-length systems that are the long projections linking the ventral tegmental and substantia nigra dopamine cell bodies with three principal sets of targets: the limbic cortex (the medial prefrontal, cingulate and entorhinal areas); other limbic structures (the regions of the septum, olfactory tubercle, nucleus accumbens, amygdaloid complex and piriform cortex); and the striatum. These groups have been termed the mesocortical, mesolimbic and nigrostriatal dopamine systems, respectively. ${ }^{18}$

Dopaminergic mechanisms within the nucleus accumbens and the striatum play an important role in the control of locomotor activity, although the nucleus accumbens is primarily involved in the initiation and regulation of such activity. Stimulation of dopaminergic neurons in these regions induces an increase in locomotor activity, whereas decreased dopamine activity elicits a depression of spontaneous locomotion. Thus, dopamine appears to be the primary neurotransmitter in inducing locomotor activity. However, the fine articulation and prolongation of locomotor activity undoubtedly involves transmitters such as norepinephrine. Furthermore, since other neurotransmitters such as acetylcholine, serotonin and especially GABA interact directly with dopamine neurons in an inhibitory capacity, any of their pathways, if sufficiently stimulated or inhibited, could considerably alter locomotor activity. ${ }^{12,25}$ In fact, both GABA and GABA receptor agonists inhibit locomotor hyperactivity induced by intracerebral injection of dopamine into the nucleus accumbens in rats. ${ }^{26,27}$

The major molecular targets of benzodiazepines are believed to be inhibitory neurotransmitter receptors directly activated by GABA. The $\mathrm{GABA}_{\mathrm{A}}$ receptor is an integral membrane chloride channel that mediates most of the rapid, inhibitory neurotransmission in the central nervous system. Benzodiazepines directly bind to the $\mathrm{GABA}_{\mathrm{A}}$ receptor-ion channel complex and allosterically modulate its activity. The distributions of GABA $_{A}$ and benzodiazepine receptors in the brain are similar. The substantia nigra, the striatum and the nucleus accumbens have a medium density of $\mathrm{GABA}_{\mathrm{A}}$ and benzodiazepine receptors. ${ }^{28,29}$ Typical benzodiazepine receptor agonists increase the amount of chloride current generated by GABAA receptor activation, potentiating the effects of GABA throughout the nervous system. Moreover, the electrophysiological effect of benzodiazepines is usually reduced or prevented by previous treatment with $\mathrm{GABA}_{\mathrm{A}}$ receptor antagonists, such as bicuculline. ${ }^{13}$ Electric stimulation of the caudate nucleus of the striatum evokes inhibitory postsy- naptic potentials in neurons recorded in the pars compacta of the substantia nigra. The evoked mass inhibitory postsynaptic potentials are found to be dose-dependently depressed by bicuculline confirming the involvement of GABA. Benzodiazepines dosedependently reverse the effect of the bicuculline. Results similar to those found on the striatonigral pathway have been obtained on the GABAergic pathway projecting from the nucleus accumbens septi to the substantia nigra zona reticulata. ${ }^{30,31}$ These electrophysiological studies support the neurochemical finding that diazepam reduces dopamine turnover in the nucleus accumbens, the olfactory tubercle and the striatum via a reduction of impulse flow of dopamine neurons in these mesolimbic and nigrostriatal dopamine systems (Table II). ${ }^{14,15}$ Furthermore, an in pivo microdialysis study has shown that diazepam reduces the release and metabolism of dopamine in the nucleus accumbens and striatum in rats. ${ }^{32}$

Ketamine increases dopamine turnover in the nucleus accumbens ${ }^{6,10}$ and the striatum ${ }^{6,10,11}$ in rodents. Electrophysiological studies have revealed that the systemic administration of ketamine increases the firing rate of slow firing dopaminergic neurons recorded in the substantia nigra. ${ }^{33}$ Ketamine also produces a dosedependent increase in the firing rate of ventral tegmental dopamine neurons. ${ }^{34}$ These findings suggest that the observed increase in dopamine turnover in the nucleus accumbers and striatum produced by ketamine can be ascribed to the increase in the firing rates of these dopamine systems. Therefore, the power of diazepam to decrease the impulse flow of dopamine neurons in the mesolimbic and nigrostriatal dopamine systems may reverse the increase in dopamine turnover in the nucleus accumbens and striatum caused by ketamine, and consequently inhibit ketamine-induced hyperlocomotion.

The present neurochemical data revealed that diazepam even at a lower dose $\left(3 \mathrm{mg} \cdot \mathrm{kg}^{-1}\right)$ completely reversed ketamine-induced increase in HVA:dopamine ratios in the nucleus accumbens and striatum (Table I). In contrast, the behavioural data showed that this dose of diazepam suppressed ketamine-induced hyperlocomotion only by $26 \%$, although a higher dose (10 $\mathrm{mg} \cdot \mathrm{kg}^{-1}$ ) returned it to the control level (Figure). Thus, there appears to be a discrepancy between the neurochemical and behavioural data. It is known that ketamine blocks the N-methyl-D-aspartate (NMDA) receptor channel as well as increases impulse flow of dopamine neurons. We recently reported that ketamine-induced hyperlocomotion is mediated not only by dopamine neurons but also, at least in part, by the NMDA receptor antagonism. ${ }^{35}$ Therefore, $3 \mathrm{mg} \cdot \mathrm{kg}^{-1}$ 
diazepam which completely reversed the ketamineinduced increase in dopamine turnover might not entirely antagonize the same dose of ketamine-induced hyperlocomotion because benzodiazepines do not affect NMDA receptors. Furthermore, we have confirmed that $3 \mathrm{mg} \cdot \mathrm{kg}^{-1}$ diazepam did not affect the anaesthetic action of ketamine, whereas $10 \mathrm{mg} \cdot \mathrm{kg}^{-1}$ potentiated this action (data not shown). Thus, the complete inhibition by $10 \mathrm{mg} \cdot \mathrm{kg}^{-1}$ diazepam of ketamine-induced hyperlocomotion might be due to this anaesthetic potentiation action in addition to the action on dopamine neurons.

In clinical studies, it has been reported that ketamine alone often induces psychic emergence reactions such as floating sensations, pleasant or unpleasant vivid dreams, hallucinations and delirium, and that benzodiazepines are the most effective agents for the prevention of these reactions. ${ }^{2,3,36}$ In addition to benzodiazepines, droperidol, a dopamine receptor antagonist, has been shown to decrease the incidence of psychic emergence reactions from ketamine. ${ }^{23,24}$ Dopamine, acting at $\mathrm{D}_{2}$ dopamine receptors, is implicated in emetic signaling through the chemoreceptor trigger zone and in the solitary tract nucleus, although serotonin, acting at $5-\mathrm{HT}_{3}$ receptors, is also thought to be an important emetic signal and transmitter. Nausea and vomiting can occur upon emergence from ketamine anaesthesia, and these symptoms might be mediated by the activation of dopamine neurons. ${ }^{37}$ Diazepam has been shown to reduce the incidence of nausea and emesis during emergence from ketamine. ${ }^{38}$ Thus, the clinical evidence appears to be supported by the present behavioural and neurochemical data.

In conclusion, our study suggests that the inhibitory action of diazepam on ketamine-induced hyperlocomotion may be related to its ability to decrease the impulse flow of dopamine neurons. Moreover, the suppression of emergence reactions to ketamine by diazepam may, at least in part, involve the interaction of diazepam with dopamine neurons.

\section{Acknowledgments}

The authors wish to thank Mr. Yoshiteru Toriire for his expert technical assistance, and Mr. Steven L. Leeper for reading the manuscript.

\section{References}

1 Domino EF, Chodoff P, Corssen G. Pharmacologic effects of CI-581, a new dissociative anesthetic, in man. Clin Pharmacol Ther 1965; 6: 279-91.

2 White PF, Way WL, Trevor AJ. Ketamine - its pharmacology and therapeutic uses. Anesthesiology 1982; 56: 119-36.
3 Reves JG, Glass PSA, Lubarsky DA. Nonbarbiturate intravenous anesthetics. In: Miller RD (Ed.). Anesthesia, 4th ed. New York: Churchill Livingstone Inc., 1994: 247-89.

4 Chen $G$, Ensor CR, Bobner B. The neuropharmacology of 2-(o-chlorophenyl)-2- methylaminocyclohexanone hydrochloride. J Pharmacol Exp Ther 1966; 152: 332-9.

5 Hetzler BE, Wautlet BS. Ketamine-induced locomotion in rats in an open-field. Pharmacol Biochem Behav $1985 ; 22$ : 653-5.

6 Irifune $M$, Shimizu $T$, Nomoto $M$. Ketamine-induced hyperlocomotion associated with alteration of presynaptic components of dopamine neurons in the nucleus accumbens of mice. Pharmacol Biochem Behav 1991; 40: 399-407.

7 Robinson TE, Becker JB. Enduring changes in brain and behavior produced by chronic amphetamine administration: a review and evaluation of animal models of amphetamine psychosis. Brain Res Rev 1986; 11: 157-98.

8 Jobanson C-E, Fischman MW. The pharmacology of cocaine related to its abuse. Pharmacol Rev 1989; 41: 3-52.

9 Fahn S. Adverse effects of levodopa. In: Olanow CW, Lieberman AN (Eds.). The Scientific Basis for the Treatment of Parkinson's Disease. Lancs: Parthenon Publishing Group Ltd., 1992: 89-112.

10 Irifune $M$, Fukuda $T$, Nomoto $M$, et al. Effects of ketamine on dopamine metabolism during anesthesia in discrete brain regions in mice: comparison with the effects during the recovery and subanesthetic phases. Brain Res 1997; 763: 281-4.

11 Vitalo $P$, Saarnivaara $L$, Abtee $L$. Effect of ketamine anaesthesia on the content of monoamines and their metabolites in the rat brain. Acta Anaesthesiol Scand 1976; 20: 216-20.

12 Fisbman RHB, Feigenbaum J, Yanai J, Klawans $H L$. The relative importance of dopamine and norepinephrine in mediating locomotor activity. Prog Neurobiol 1983; 20: 55-88.

13 Hobbs WR, Rall TW, Verdoorn TA. Hypnotics and sedatives; ethanol. In: Hardman JG, Limbird LE, Molinoff PB, Ruddon RW, Gilman AG (Eds.). Goodman \& Gilman's The Pharmacological Basis of Therapeutics, 9th ed. New York: McGraw-Hill Companies Inc., 1996: 361-96.

14 Fuxe $K$, Agnati LF, Bolme $P$, et al. The possible involvement of GABA mechanisms in the action of benzodiazepines on central catecholamine neurons. In: Costa $\mathrm{E}$, Greengard P (Eds.). Mechanism of Action of Benzodiazepines. New York: Raven Press Books Ltd., 1975: 45-61. 
15 Ishiko J, Inagaki C, Takaori S. Effects of diazepam, nitrazepam and brotizolam on dopamine turnover in the olfactory tubercle, nucleus accumbens and caudate nucleus of rats. Jpn J Pharmacol 1983; 33: 706-8.

16 Heffner TG, Hartman JA, Seiden LS. A rapid method for the regional dissection of the rat brain. Pharmacol Biochem Behav 1980; 13: 453-6.

17 Korf J. Turnover of neurotransmitters in the brain: an introduction. In: Pycock CJ , Taberner PV (Eds.). Central Neurotransmitter Turnover. London: Croom Helm Ltd., 1981: 1-19.

18 Cooper JR, Bloom FE, Roth RH. The Biochemical Basis of Neuropharmacology, 7th ed. New York: Oxford University Press, 1996.

19 Sharman DF. The turnover of catecholamines. In: Pycock CJ, Taberner PV (Eds.). Central Neurotransmitter Turnover. London: Croom Helm Ltd., 1981: 20-58.

20 Chiodo LA, Bannon MJ, Grace AA, Roth RH, Bunney $B S$. Evidence for the absence of impulse-regulating somatodendritic and synthesis-modulating nerve terminal autoreceptors on subpopulations of mesocortical dopamine neurons. Neuroscience 1984; 12: 1-16.

21 Wolf $M E$, Roth $R H$. Dopamine autoreceptors. In: Creese I, Fraser CM (Eds.). Dopamine Receptors. New York: Alan R Liss Inc., 1987: 45-96.

22 Uchibashi $\Upsilon$, Kuribara H, Tadokoro S. Assessment of the ambulation-increasing effect of ketamine by coadministration with central-acting drugs in mice. Jpn J Pharmacol 1992; 60: 25-31.

23 Sadove MS, Hatano S, Zabed B, Redlin T, Arastounejad $P$, Roman $V$. Clinical study of droperidol in the prevention of the side effects of ketamine anesthesia: a preliminary report. Anesth Analg 1971; 50: 388-93.

24 Becsey L, Malamed S, Radnay P, Foldes FF. Reduction of the psychotomimetic and circulatory side-effects of ketamine by droperidol. Anesthesiology 1972; 37: $536-42$.

25 Arnt $J$. Behavioral studies of dopamine receptors: evidence for regional selectivity and receptor multiplicity. In: Creese I, Fraser CM (Eds.). Dopamine Receptors. New York: Alan R Liss Inc., 1987: 199-231.

26 Pycock CJ, Horton RW. Dopamine-dependent hyperactivity in the rat following manipulation of GABA mechanisms in the region of the nucleus accumbens. J Neural Transm 1979; 45: 17-33.

27 Slater P, Longman DA, Dickinson SL. Effects of intrapallidal drugs on hyperactivity induced by nucleus accumbens dopamine receptor stimulation. NaunynSchmiedeberg's Arch Pharmacol 1982; 321: 201-6.

28 Lloyd KG, Shemen L, Hornykiewicz O. Distribution of high affinity sodium-independent $\left[{ }^{3} \mathrm{H}\right]$ gammaaminobutyric acid $\left(\left[{ }^{3} \mathrm{H}\right] \mathrm{GABA}\right)$ binding in the human brain: alterations in Parkinson's disease. Brain Res 1977; 127: 269-78.

29 Möbler H, Okada T. Biochemical identification of the site of action of benzodiazepines in human brain by ${ }^{3} \mathrm{H}$-diazepam binding. Life Sci 1978; 22: 985-96.

30 Haefely W, Kulcsár A, Möbler H, Pieri L, Polc P, Schaffner $R$. Possible involvement of GABA in the central actions of benzodiazepines. In: Costa $\mathrm{E}$, Greengard P (Eds.). Mechanism of Action of Benzodiazepines. New York: Raven Press Books Ltd, 1975: 131-51.

31 Haefely W, Polc P. Physiology of GABA enhancement by benzodiazepines and barbiturates. In: Olsen RW, Venter JC (Eds.). Benzodiazepine/GABA Receptors and Chloride Channels: Structural and Functional Properties. New York: Alan R Liss Inc., 1986: 97-133.

32 Invernizzi R, Pozzi L, Samanin R. Release of dopamine is reduced by diazepam more in the nucleus accumbens than in the caudate nucleus of conscious rats. Neuropharmacology 1991; 30: 575-8.

33 Raja SN, Guyenet PG. Effects of phencyclidine on the spontaneous activity of monoaminergic neurons. Eur J Pharmacol 1980; 63: 229-33.

34 French ED, Ceci $A$. Non-competitive $N$-methyl-Daspartate antagonists are potent activators of ventral tegmental $A_{10}$ dopamine neurons. Neurosci Lett 1990; 119: 159-62.

35 Irifune $M$, Shimizu $T$, Nomoto $M$, Fukuda $T$. Involvement of $N$-methyl-D-aspartate (NMDA) receptors in noncompetitive NMDA receptor antagonistinduced hyperlocomotion in mice. Pharmacol Biochem Behav 1995; 51: 291-6.

36 Reich $D L$, Silvay $G$. Ketamine: an update on the first twenty-five years of clinical experience. Can J Anaesth 1989; 36: 186-97.

37 Brunton LL. Agents affecting gastrointestinal water flux and motility; emesis and antiemetics; bile acids and pancreatic enzymes. In: Hardman JG, Limbird LE, Molinoff PB, Ruddon RW, Gilman AG (Eds.). Goodman \& Gilman's The Pharmacological Basis of Therapeutics, 9th ed. New York: McGraw-Hill Companies Inc., 1996: 917-36.

38 Mattila MAK, Larni HM, Nummi SE, Pekkola PO. Effect of diazepam on emergence from ketamine anaesthesia. A double-blind study. Anaesthesist 1979; 28: 20-3. 